\title{
Pengaruh Profitabilitas, Ukuran Perusahaan, Kepemilikan Manajemen dan Media Exposure Pada Pengungkapan Corporate Social Responsibility
}

\author{
Ketut Yoga Permadiswara ${ }^{1}$ \\ Ketut Sujana ${ }^{2}$
}

\author{
${ }^{1}$ Fakultas Ekonomi dan Bisnis Universitas Udayana (Unud), Bali, Indonesia \\ email: ypermadiswa@gmail.com/ Telp: 083119945897 \\ ${ }^{2}$ Fakultas Ekonomi dan Bisnis Universitas Udayana (Unud), Bali, Indonesia
}

\begin{abstract}
ABSTRAK
Munculnya kesadaran bahwa kegiatan produksi secara tidak langsung akan berdampak pada lingkungan misalkan penggundulan hutan, pembuangan limbah, pencemaran udara dan sebagainya. Hal itu membuat perusahaan wajib untuk bertanggung jawab atas aktivitasnya tersebut. Tujuan penelitian ini untuk mendapatkan bukti empiris pengaruh tingkat profitabilitas, ukuran perusahaan, kepemilikan manajemen dan media exposure pada pengungkapan corporate social responsibility (CSR) dalam laporan tahunan perusahaan manufaktur yang terdaftar di Bursa Efek Indonesia Metode penentuan sampel yang digunakan adalah purposive sampling.Jumlah perusahaan yang memenuhi kriteria adalah 22 perusahaan manufaktur yang terdaftar di Bursa Efek Indonesia tahun 20142016 dengan jumlah 66 amatan.Teknik analisis data yang digunakan adalah Regresi Linier Berganda.Berdasarkan hasil analisis, diketahui bahwa profitabilitas, ukuran perusahaan dan media exposure berpengaruh positif pada pengungkapan corporate social responsibility.Hasil penelitian ini juga menunjukan kepemilikan manajemen tidak berpengaruh pada pengungkapan corporate social responsibility.

Kata Kunci: profitabilitas, ukuran perusahaan, kepemilikan manajemen, media exposure,corporatesocial responsibility
\end{abstract}

\begin{abstract}
The emergence of awareness that production activities will indirectly affect the environment eg deforestation, waste disposal, air pollution and so forth. It makes the company obliged to take responsibility for its activities. The purpose of this study is to obtain empirical evidence of the influence of the level of profitability, firm size, management ownership and media exposure on CSR in the annual report of manufacturing companies listed on Indonesia Stock Exchange. The method of determining the sample used is purposive sampling. Number of companies that meet the criteria are 22 manufacturing companies listed on the IDX 2014-2016 year with 66 amount amatan.Teknik data analysis used is Multiple Linear Regression.Based on the analysis, it is known that profitability, firm size and media exposure have a positive effect on disclosure of corporate social responsibility. The results of this study also show that management ownership has no effect on corporate social responsibility disclosure.

Keywords: profitability, firm size, management ownership, media exposure, corporate social responsibility
\end{abstract}

\section{PENDAHULUAN}

Era globalisasi menyebabkan dunia bisnis berkembang pesat dan menimbulkan persaingan antara perusahaan semakin ketat yang mendorong perusahaan 
Ketut Yoga Permadiswara dan Ketut Sujana. Pengaruh...

berupaya semaksimal mungkin untuk mencapai setiap tujuannya. Berkembangnya sejarah akuntansi menyebabkan pelaporan akuntansi sering digunakan sebagai alat pertanggung jawaban kepada pemilik modal mengakibatkan orientasi perusahaan lebih berpihak pada pemilik modal. Dimana pada sistem akuntansi ini perusahaan berfokus pada pemilik modal dan mengabaikan masalah sosial dan lingkungan. Perusahaan yang lebih berpihak kepemilik modal akan mengakibatkan eksploitasi sumber daya alam dan ketidak pedulian kepada masyarakat secara tidak terkendali yang berdampak pada kerusakan lingkungan jangka dekat maupun jangka panjang.

Dewasa ini perusahaan tidak hanya mementingkan profit dan kegiatan produksi tapi juga harus memperhatikan lingkungan sekitar. Munculnya kesadaran bahwa kegiatan produksi secara tidak langsung akan berdampak pada lingkungan misalkan penggundulan hutan, pembuangan limbah, pencemaran udara dan sebagainya. Hal itu membuat perusahaan wajib untuk bertanggung jawab atas aktivitasnya tersebut. Kegiatan sosial ini disebut Corporate Sosial Respostibility (CSR).

Corporate Social Responsibility atau CSR tidak lagi kegiatan yang dilakukan perusahaan dengan sukarela, tetapi sudah di atur dalam UndangUndang R.I. No. 40 tahun 2007 pasal 74 ayat (1) tentang tanggung jawab sosial dan lingkungan menjelaskan "Perseroan yang menjalankan kegiatan usahanya di bidang dan atau berkaitan dengan sumber daya alam wajib melaksanakan tanggung jawab sosial dan lingkungan”. Tanggung jawab lingkungan dan sosial merupakan kewajiban perseroan yang dianggarkan dan diperhitungkan sebagai 
biaya perseroan yang pelaksanaannya dilakukan dengan meperhatikan kepatutan dan kewajaran. Perseroan yang melanggar akan dikenai sanksi sesuai dengan ketentuan peraturan perundang-undangan.

IAI dalam PSAK No.1 (revisi 2009) paragraf 12 menyarankan perusahaan untuk mengungkapkan tanggung jawab jawab akan masalah lingkungan dan sosial yaitu "Entitas dapat pula menyajikan, terpisah dari laporan keuangan, laporan mengenai lingkungan hidup dan laporan nilai tambah (value added statement), khususnya bagi industri dimana faktor lingkungan hidup memegang peranan penting dan bagi industri yang menganggap karyawan sebagai kelompok pengguna laporan yang memegang peranan penting. Laporan tambahan tersebut di luar ruang lingkup Standar Akuntansi Keuangan”.

Dengan adanya PSAK no. 1 tersebut perusahaan diharapkan memiliki kesadaran dan bertanggung jawab atas lingkungan terutama perusahaan industri yang meninggalkan limbah, karena jika limbah tersebut tidak diolah terlebih dahulu secara tidak langsung akan mencemari lingkungan dan akan berdampak pada kehidupan sosial (Farida dkk., 2017). PSAK 57 hanya mengatur tentang provisi, liabilitas kontijensi, dan aset kontijensi. Program penilaian peringkat kinerja perusahaan dalam pengelolaan lingkungan hidup atau yang lebih dikenal dengan PROPER diadakan oleh Kementrian Lingkungan Hidup (KLH). Melalui PROPER kinerja lingkungan perusahaan diukur dengan menggunakan warna mulai yang terbaik diberi warna emas, hijau, biru, merah, hingga yang terburuk hitam. 
Tabel 1.

Distribusi Per Sektor Industri PROPER 2006-2007

\begin{tabular}{ccccccc}
\hline Peringkat & Manufaktur & Agroindustri & PEM & $\begin{array}{c}\text { Kawasan } \\
\text { \& Jasa }\end{array}$ & Total & \% \\
\hline Emas & - & - & 1 & - & 1 & 0,19 \\
Hijau & 22 & 3 & 20 & 1 & 46 & 8,91 \\
Biru & 76 & 34 & 71 & 7 & 188 & 36,43 \\
Biru Minus & 85 & 34 & 33 & 4 & 156 & 30,23 \\
Merah & 21 & 12 & 10 & 2 & 45 & 8,72 \\
& & & & & & 38 \\
Merah Minus & 18 & 8 & 11 & 1 & 42 & 8,14 \\
Hitam & 29 & 11 & & - & 516 & \\
\hline Total & 251 & 102 & 148 & 15 & & \\
\hline
\end{tabular}

Sumber: www.proper.menlh.go.id

Dapat dilihat dalam Tabel 1. terdapat 42 perusahaan yang termasuk peringkat hitam, 29 diantaranya adalah perusahaan manufaktur. Hal ini menandakan ketidaktaatan perusahan terhadap peraturanperaturan yang menyangkut tentang kelestarian lingkungan. Aktivitas yang dilakukan perusahaan manufaktur sering menimbulkan dampak bagi lingkugan dan sekitarnya.

Profitabilitas merupakan suatu indikator kinerja yang dilakukan manajemen dalam mengelola kekayaan perusahaan yang ditunjukkan oleh laba yang dihasilkan. Perusahaan mengeluarkan biaya untuk tanggung jawab sosial ini, tapi seiring berjalannya waktu perusahaan mendapatkan citra yang baik di masyarakat dan loyalitas konsumen yang lebih besar terutama dalam hal produk-produk yang bersifat ramah lingkungan. Kokobu et al. (2001) dalam Sembiring (2005) menyatakan bahwa adanya hubungan positif antara kinerja ekonomi suatu perusahaan dengan pengungkapan tanggung jawab sosial. Hal ini dikaitkan dengan teori agensi bahwa perolehan laba yang semakin besar akan membuat perusahaan mengungkapkan informasi sosial yang lebih luas. 
Perusahaan yang memiliki perolehan laba rendah akan lebih mengutamakan untuk memperoleh profit yang lebih besar daripada mengungkapkan informasi sosial yang akan mengeluarkan biayasehingga pengungkapan corporate social responsibility tidak maksimal. Donovan dan Gibson (2000) dalam Sembiring (2005) menyatakan bahwa berdasarkan teori legitimasi profitabilitas tidak berpengaruh terhadap pengungkapan tanggung jawab sosial perusahaan, hal ini didukung dengan argumentasi bahwa ketika perusahaan memiliki tingkat laba yang tinggi, manajemen perusahaan menganggap tidak perlu melaporkan hal-hal yang dapat mengganggu informasi tentang sukses keuangan perusahaan. Sebaliknya, pada saat tingkat profitabilitas rendah, mereka berharap para pengguna laporan akan membaca good news kinerja perusahaan, misalnya dalam lingkup sosial, dengan demikian investor akan tertarik dan tetap berinvestasi di perusahaan tersebut.

Ukuran perusahaan menjadi salah satu faktor yang mempengaruhi pngungkapan CSR di perusahaan. Penelitian Hackston dan Milne (1996) menunjukan adanya pengaruh ukuran perusahaan dalam pengungkapan pertanggungjawaban sosial perusahasan, dimana perusahaan yang lebih besar cenderung akan lebih banyak dalam pengungkapan informasi pertanggungjawaban sosialnya dari pada perusahaan yang lebih kecil. Disamping itu perusahaan kecil akan lebih fokus pada peningkatan penjualan dari pada pengungkapan CSR.

Jensen dan Meckling (1976) ketika kepemilikan manajer terhadap perusahaan semakin kecil maka konflik kepentingan antara manajer dengan 
Ketut Yoga Permadiswara dan Ketut Sujana. Pengaruh...

pemilik menjadi semakin besar. Media exposure merupakan varibel yang jarang digunakan untuk menjelaskan pengaruhnya terhadap pengungkapan CSR. Pengkomunikasian CSR melalui media penting untuk meningkatkan reputasi perusahaan di mata masyarakat. Anggraini (2006) teori legitimasi secara luas mengujji peran yang dimainkan oleh berita media pada peningkatan tekanan yang diakibatkan oleh tututan publik terhadap perusahaan. Gamerschlag et al. (2011) menyatakan pengungkapan lingkungan dan sosial pada perusahaan perusahaan di Jerman yang menunjukan bahwa ukuran perusahaan dan industri berhubungan dengan jumlah pengungkapan lingkungan sosial sedangkan profitabilitas tidak berpengaruh.

Penelitian terhadap 46 perusahaan yang terdaftar di bursa efek Spanyol pada tahun 2008 oleh Reverte (2009) menunjukkan bahwa ukuran perusahaan, sensitivitas industri, media exposure, berpengaruh positif terhadap indeks pengungkapan CSR perusahaan. Sedangkan profitabilitas perusahaan, struktur kepemilikan perusahaan, international listing, leverage, tidak mempunyai pengaruh yang signifikan pada indeks pengungkapan CSR. Ingram and Frazier (1980), Wiseman (1982) dan Rockness (1985) menunjukan eksposur media tidak berpengaruh pada pengungkapan informasi lingkungan. Anggraini (2006) kepemilikan manajemen berpengaruh positif terhadap pengungkapan Corporate Social Responsibility dan profitabilitas tidak berpengaruh terhadap pengungkapan Corporate Social Responsibility. Gray et al. (1995) menyatakan bahwa sifat dan volume pelaporan mengenai pertanggungjawaban sosial perusahaan bervariasi 
antar waktu dan antar negara, hal ini disebabkan isu-isu yang dipandang penting oleh satu negara mungkin akan menjadi kurang penting bagi negara lain.

Tujuan penelitian yang dapat dirumuskan adalah untuk mengetahui dan mendapatkan bukti empiris bahwa untuk mendapatkan bukti empiris pengaruh tingkat profitabilitas, ukuran perusahaan, kepemiilikan manajemen, dan media exposure pada pengungkapan corporate social responsiblity.Penelitian ini mampu menyumbangkan bukti empiris mengenai Hasil penelitian ini dapat memberikan tambahan pengetahuan dan wawasan khususnya mengenai pengungkapan corporate social responsibility (CSR) dan faktor-faktor yang mempengaruhi pengungkapan corporate social responsibility (CSR) dalam laporan tahunan perusahaan manufaktur di Indonesia. Hasil penelitian dapat memberikan manfaat kepada perusahaan, khususnya para pemakai laporan keuangan dan manajemen perusahaan dalam memahami peranan praktek Corporate Social Responsibility yang dilakukan perusahaan. Dapat memberikan gambaran tentang laporan keuangan tahunan sehingga dapat dijadikan sebagai acuan untuk pengambilan keputusan investasi.

Teori keagenan (agency theory) mengungkapkan adanya hubungan antara principal (pemilik) dan agent (manajer) yang dilandasi dari adanya pemisahan kepemilikan dan pengendalian perusahaan, pemisahan penanggung resiko, pembuatan keputusan dan pengendalian fungsi-fungsi (Jensen dan Meckling, 1976). Teori keagenan muncul untuk mengatasi konflik agensi yang dapat terjadi dalam hubungan keagenan. Berdasarkan teori agensi perusahaan yang menghadapi biaya kontrak dan biaya pengawasan yang rendah lebih cenderung 
Ketut Yoga Permadiswara dan Ketut Sujana. Pengaruh...

akan melaporkan laba bersih rendah atau mengeluarkan biaya-biaya untuk kepentingan manajemen, salah satunya biaya yang dapat meningkatkan reputasi perusahaan di masyarakat. Kemudian, sebagai wujud pertanggungjawaban, manajer sebagai agent akan berusaha memenuhi seluruh keinginan pihak principal yaitu pengungkapan informasi pertanggungjawaban sosial perusahaan.

Perusahaan akan melaporkan aktivitasnya secara sukarela jika manajemen mengaanggap bahwa hal ini yang diharapkan oleh masyarakat pada umumnya. Dalam teori legitimasi, organisasi harus secara berkelanjutan menunjukan telah beroprasi dalam prilaku yang konsisten dengan nilai sosial. Adanya teori legitimasi menganjurkan perusahaan untuk meyakinkan bahwa aktivitas dan kinerjanya diterima oleh masyarakat dan memberikan perusahaan landasan bahwa perusahaan harus mentaati norma-norma yang berlaku dimasyarakat dimana perusahaaan beroprasi, agar tidak terjadi konflik dari masyarakat sekitar sehingga aktivitas perusahaan dapat berjalan dengan lancar. Barkemeyer (2007) penjelasan tentang kekuatan teori legitimasi organisasi dalam konteks tanggung jawab sosial perusahaan di negara berkembang terdapat dua hal pertama, kapabilitas untuk menempatkan motif maksimalisasi keuntungan membuat gambaran lebih jelas tentang motivasi perusahaan memperbesar tanggung jawab sosialnya. Kedua, legitimasi organisasi dapat untuk memasukkan faktor budaya yang membentuk tekanan institusi yang berbeda dalam konteks yang berbeda.

Teori legitimasi merupakan salah satu teori yang mendasari pengungkapan CSR. Pengungkapan tanggung jawab sosial perusahaan dilakukan untuk mendapatkan nilai positif dan legitimasi dari masyarakat. Perusahaan 
menggunakan laporan tahunan mereka untuk menggambarkan kesan langsung tannggung jawab sosial dan lingkungan, sehingga mereka diterima oleh masyarakat. Dengan adanya CSR, perusahaan dapat memberikan kontribusi positif kepada masyarakat sekitar sehingga masyarakat dapat menerima baik keberadaan perusahaan dilingkungan.

Profitabilitas merupakan faktor yang membuat manajemen menjadi bebas dan fleksibel untuk mengungkapkan corporate social responsibility kepada stakeholder, sehingga semakin tinggi profatibilitas perusahaan maka akan semakin besar pula pengungkapannya.Kokobu et al. (2001) dalam Sembiring (2005) menyatakan bahwa adanya hubungan positif antara kinerja ekonomi suatu perusahaan dengan pengungkapan tanggung jawab sosial. Hal ini dikaitkan dengan teori agensi dengan premis bahwa perolehan laba yang semakin besar akan membuat perusahaan mengungkapkan informasi sosial yang lebih luas.

Hasil penelitian yang dilakukan oleh Linda dan Erlin (2012) dan Sakania dan Merta (2011) menyatakan bahwa profitabilitas berpengaruh positif terhadap pengungkapan CSR.Berdasarkan penjelasan di atas, maka dapat disimpulkan hipotesis sebagai berikut:

$\mathrm{H}_{1}$ : Profitabilitas berpengaruh positif pada pengungkapan corporate social responsibility.

Ukuran perusahaan menjadi salah satu variabel yang sering digunakan untuk menjelaskan pengungkapan sosial yang dilakukan perushaan dalam laporan tahunan yang dibuat. Sembiring (2005) menyatakan bahwa ukuran perusahaan berpengaruh terhadap pengungkapan informasi tanggung jawab sosial karena perusahaan-perusahaan besar merupakan emiten yang banyak disoroti. Dermawan 
Ketut Yoga Permadiswara dan Ketut Sujana. Pengaruh...

dan Deitiana (2014) menyatakan ukuran prusahaan berpengaruh positif terhadap pengungkapan CSR. Semakin besar suatu perusahaan maka akan memiliki biaya keagenan yang lebih besar sehingga akan mengungkapkan informasi sosial yang lebih luas agar mendapatkan kesan positif dari pemilik modal. Berdasarkan penjelasan di atas, maka dapat disimpulkan hipotesis sebagai berikut:

$\mathrm{H}_{2}$ : Ukuran perusahaan berpengaruh positif pada pengungkapan corporate social responsibility.

Teori keagenan menjelaskan bahwa kepentingan agent dan principal bertentangan. Hal tersebut disebabkan manajer mengutamakan kepentingan pribadi, sebaliknya pemegang saham tidak menyukai kepentingan pribadi manajer tersebut, karena pengeluaran tersebut akan menambah biaya perusahaan yang menyebabkan penurunan keuntungan perusahaan dan penurunan deviden yang akan diterima.

Jensen \& Meckling (1976) menyatakan bahwa konflik kepentingan antara manajer dengan pemilik menjadi semakin besar ketika kepemilikan manajer terhadap perusahaan semakin kecil. Penelitian yang dilakukan oleh Anggraini (2006) hasilnya ditemukan terdapat hubungan antara kepemilikan manajerial dan CSR.Berdasarkan penjelasan di atas, maka dapat disimpulkan hipotesis sebagai berikut:

$\mathrm{H}_{3}$ : Kepemilikan manajemen berpengaruh positif pada pengungkapan corporate social responsibility.

Media exposure dalam penelitian ini dimaksudkan untuk melihat sejauh mana perusahaan menggunakan internet untuk mengkomunikasikan aktivitas CSR dalam media website. Pemakaian internet yang semakin meningkat mendukung peerusahaan untuk mengkomunikasikan aktivitas CSR.Sari (2012) dalam (Kristi, 
2012) menyatakan website merupakan media yang paling efektif digunakan. Jika CSR diungkapkan di media maka perusahaan akan lebih sering melakukan CSR untuk meningkatkan reputasi perusahaan (Dermawan dan Deitiana, 2014).

Hasil penelitian dari Respati dan Hadiprajitno (2015), Kristi (2012) dan Reverte (2009) media exposure berpengaruh positif terhadap pengungkapan CSR.Berdasarkan penjelasan di atas, maka dapat disimpulkan hipotesis sebagai berikut:

$\mathrm{H}_{4}$ : Media exposure berpengaruh positif pada pengungkapan corporate social responsibility.

\section{METODE PENELITIAN}

Lokasi dalam penelitian ini yaitu di Bursa Efek Indonesia (BEI) dengan mengakses website www.idx.co.id dan mengunduh laporan keuangan tahunan perusahaan manufaktur sebagai data di tahun 2014-2016.Objek Penelitian adalah suatu sifat dari objek yang ditetapkan oleh peneliti untuk dipelajari dan diperoleh kesimpulannya (Sugiyono, 2017:13). Objek penelitian ini adalah Perusahaanperusahaan manufaktur yang terdaftar di Bursa Efek Indonesia (BEI) pada periode 2014-2016.

Pengungkapan CSR merupakan pengungkapan informasi yang terkait dengan pertanggung jawaban sosial perusahaan atau pengkomuniksian dampak sosial dan lingkungan akibat dari aktivitas perusahaan terhadap pemegang saham, kreditur, karyawan, dan masyarakat secara keseluruhan. Alexander (2008) menggunakan pengungkapan corporate social resposibilityyang diproksikan dalam jumlah pengungkapan yang berpedoman pada kategori pengungkapan 
Ketut Yoga Permadiswara dan Ketut Sujana. Pengaruh...

corporate social responsibility. Pengungkapan tersebut terdiri dari 6 kategori pengungkapan yaitu: kinerja ekonomi, kinerja lingkungan, praktik kerja, hak manusia, sosial, dan tanggung jawab produk. Masing-masing kategori pengungkapan diberi skor 1 sehingga jika perusahaan mengungkapkan 1 item saja maka skor yang diperoleh adalah 1, sedangkan kelompok perusahaan yang tidak mengungkapkan informasi pertanggungjawaban sosial akan diberi angka 0. Jadi jumlah skor maksimal jika perusahaan mengungkapkan semua item kategori pengungkapan corporate social responsibility adalah 6.

$$
n(C S R)=\frac{\text { Jumlah Total Pengungkap an CSR }}{\text { Skor maksimal }}
$$

Keterangan:

$\mathrm{n}(\mathrm{CSR})=$ Skor Pengungkapan corporate social responsibility

Profitabilitas dapat dihitung dengan rasio Return On Assets (ROA) yang menunjukan kemampuan perusahaan menghasilkan laba dari aktiva yang dipergunakan. Rasio ini memberikan ukuran yang lebih baik atas profitabilitas karena menunjukan efektifitas manajemen dalam menggunakan aktiva untuk memperoleh pendapatan (Yuliskayani dan Damayanthi, 2018). ROA dapat di hitung dengan rumus:

$$
R O A=\frac{\text { laba bersi h setela } h \text { pajak }}{\text { total aset }}
$$

Ukuran perusahaan merupakan ukuran besar kecilnya peerusahaan berdasarkan totak aktiva yang dimiliki oleh prusahaan. Linda dan Erlin (2012) 
ukuran perusahaan diukur dengan logaritma natural dari total aktiva. Proksi tersebut mampu menggambarkan total aktiva :

$$
\text { Size }=\text { Ln (total Aset) }
$$

Kepemilikan manajemen adalah kepemilikan yang dimiliki oleh manajer, dewan direksi dan dewan komisaris. Nilai kepemilikan manajemen dapat diukur dengan rumus :

$$
\text { Kepemilikan manajemen: } \frac{\text { saham manajemen }}{\text { saham yang beredar }} \text {. }
$$

Mengukur pengungkapan media atau media exposure dilakukan dengan variabel dummy, yaitu dengan memberikan nilai 1 untuk perusahaan yang mengkomunikasikan kegiatan CSR di website perusahaan dan 0 untuk perusahaan yang tidak mengungkapkan kegiatan CSR di website perusahaan.

Populasi yang digunakan adalah seluruh perusahaan manufaktur yang tercatat di Bursa Efek Indonesia pada tahun 2014-2016 dengan teknik purposive sampling. Metode yang digunakan adalah metode observasi non partisipan dimana peneliti tidak terlibat secara langsung dalam proses observasi tapi hanya sebagai pengamat indepeden. Penelitian ini dilakukan bersumber dari www.idx.co.id, website perusahaan, buku-buku, skripsi dan jurnal-jurnal yang terkait.

Data yang digunakan adalah data sekunder. Metode ini merupakan metode pengumpulan data dengan cara mengumpulkan dokumen-dokumen yang berhubungan dengan ketepatan waktu penyampaian laporan keuangan. Sumber data penelitian ini diperoleh www.idx.co.id.

Penelitian ini dilakukan uji asumsi klasik terlebih dahulu kemudian dilakukan teknik analisis data. Teknik analisis data dalam penelitian ini 
Ketut Yoga Permadiswara dan Ketut Sujana. Pengaruh...

menggunakan uji Regresi Linear Berganda. Adapun model rumus persamaan yang digunakan dalam penelitian ini adalah sebagai berikut:

$$
Y=a+\beta_{1} X_{1}+\beta_{2} X_{2}+\beta_{3} X_{3}+\beta_{4} X_{4}+\varepsilon
$$

\section{Keterangan :}

$$
\begin{array}{ll}
\mathrm{Y} & =\text { Pengungkapan CSR } \\
\mathrm{a} & =\text { konstanta } \\
\beta & =\text { koefisien regresi } \\
\mathrm{X} 1 & =\text { Profitabilitas } \\
\mathrm{X} 2 & =\text { Ukuran perusahaaan } \\
\mathrm{X} 3 & =\text { Kepemilikan manajemen } \\
\mathrm{X} 4 & =\text { Media exposure }
\end{array}
$$

\section{HASIL DAN PEMBAHASAN}

Penelitian ini di lakukan untuk mengetahui pengaruh profitabilitas, ukuran perusahaan, kepemilikan manajemen dan media exposure pada pengungkapan corporate social responsibility. Data sekunder yang diperoleh kemudian dipilih berdasarkan kriteria-kriteria yang telah ditentukan.

Tabel 2.

Proses Pemilihan Sampel

\begin{tabular}{lcc}
\hline \multicolumn{1}{c}{ Kriteria } & $\begin{array}{c}\text { Jumlah } \\
\text { Perusahaan }\end{array}$ \\
\hline Jumlah seluruh perusahaan manufaktur yang terdaftar di BEI pada tahun & 141 \\
$2014-2016$ & & $(95)$ \\
Jumlah perusahaan yang datanya tidak mengungkapkan kepemilikan & \\
manajemen & & $(1)$ \\
Jumlah perusahaan yang datanya tidak mengungkapkan corporate social & $(15)$ \\
responsibility & & $(5)$ \\
Jumlah perusahaan yang rugi & 25 \\
Jumlah perusahaan yang tidak memakai rupiah & 75 \\
Total perusahaan yang diteliti & & $(9)$ \\
Total Observasi 2014-2016 & 66 \\
Data Outlier & & \\
Total observasi akhir & & \\
\end{tabular}

Sumber: Data diolah, 2017 
Lokasi penelitian ini yaitu perusahaan manufaktur yang terdaftar di Bursa Efek Indonesia (BEI) pada periode 2014-2016, dengan mengakses situs www.idx.co.id. Tabel 2 menunjukkan bahwa terdapat 22 perusahaan manufaktur yang terdaftar di BEI pada tahun 2014-2016 yang layak digunakan sebagai sampel penelitian. Periode pengamatan adalah 3 tahun sehingga terdapat 66 sampel yang akan diamati.

Statistik deskriptif digunakan untuk memberikan informasi mengenai karakteristik variabel-variabel penelitian, yaitu jumlah sampel, nilai rata-rata (Mean), nilai minimum dan maksimum, serta standar deviasi pada variabelvariabel yang diteliti. Hasil Statistik deskriptif dapat dilihat pada Tabel 3 sebagai berikut.

Tabel 3.

Stastik Deskriptif

\begin{tabular}{|c|c|c|c|c|c|}
\hline & $\mathbf{N}$ & Minimum & Maximum & Mean & Std. Deviation \\
\hline Profitabilitas & 66 & 0,00 & 0,26 & 0,0666 & 0,05599 \\
\hline Ukuran Perusahaan & 66 & 25,62 & 33,20 & 28,4812 & 1,95425 \\
\hline Kepemilikan Manajemen & 66 & 0,00 & 0,34 & 0,0793 & 0,09419 \\
\hline Media Exposure & 66 & 0,00 & 1,00 & 0,6818 & 0,46934 \\
\hline Pengungkapan CSR & 66 & 0,33 & 1,00 & 0,6439 & 0,22999 \\
\hline Valid N (listwise) & 66 & & & & \\
\hline
\end{tabular}

Sumber: Data diolah, 2018

Variabel Profitabilitas memiliki nilai terendah (minimum) sebesar 0 persen yaitu perusahaan INDS, sedangkan nilai tertinggi (maksimum) sebesar 0,26 persen yaitu perusahaan TCID. Mean dari profitabilitas sebesar 0,0666 persen artinya bahwa rata-rata profitabilitas pada 22 perusahaan pada tahun 2014-2016 adalah 0,0666 satuan. Nilai rata-rata profitabilitas lebih mendekati nilai minimum, hal ini berarti rata-rata profitabilitas pada perusahaan manufaktur pada tahun 2014-2016 cenderung rendah. Simpangan baku (standar deviasi) sebesar 0,05599 
persen. Nilai devisiasi yang lebih kecil dari nilai rata-rata artinya terdapat fluktasi yang rendah pada profitabilitas di perusahaan yang menjadi sampel.

Variabel ukuran perusahaan memiliki nilai terendah (minimum) sebesar 25,62 persen yaitu perusahaan SKBM, sedangkan nilai tertinggi (maksimum) sebesar 33,20 persen yaitu perusahaan ASII. Mean dariukuran perusahaan sebesar 28,4812 persen.Nilai rata-rata ukuran perusahaan lebih mendekati nilai minimum, hal ini berarti rata-rata ukuran perusahaan pada perusahaan manufaktur pada tahun 2014-2016 cenderung rendah. Simpangan baku (standar deviasi) sebesar 1,95425. Nilai devisiasi yang lebih kecil dari nilai rata-rata artinya terdapat fluktasi yang rendah pada ukuran perusahaan di perusahaan yang menjadi sampel.

Variabel kepemilikan manajemen memiliki nilai terendah (minimum) sebesar 0,00 persen yaitu perusahaan LMPI, sedangkan nilai tertinggi (maksimum) sebesar 0,34 persenyaitu perusahaan INCI. Mean dari kepemilikan manajemen sebesar 0,0793 persen. Nilai rata-rata kepemilikan manajemen lebih mendekati nilai minimum, hal ini berarti rata-rata kepemilikan manajemen pada perusahaan manufaktur pada tahun 2014-2016 cenderung rendah. Simpangan baku (standar deviasi) sebesar 0,09419 persen. Nilai devisiasi yang lebih besar dari nilai rata-rata artinya terdapat fluktasi yang cukup tinggi pada kepemilikan manajemen di perusahaan yang menjadi sampel.

Variabel media exposure memiliki nilai terendah (minimum) sebesar 0 yaitu perusahaan INCI, APLI, INDS, SKLT dan PYFA yang artinya perusahaantidak mengkomunikasikan kegiatan CSR di website terkini perusahaan, sedangkan nilai tertinggi (maksimum) sebesar 1 yaitu perusahaanAMFG, LION, LMSH, DPNS, 
TRST, ALDO, ASII, SMSM, INDF, ULTJ, GGRM, WIIM, KAEF, TSPC dan TCIDyang artinya perusahaan mengungkapkan kegiatan CSR di website terkini perusahaan. Mean media exposure sebesar 0,6818. Nilai rata-rata media exposure lebih mendekati nilai maksimum, hal ini berarti rata-rata media exposure pada perusahaan manufaktur pada tahun 2014-2016 cenderung tinggi. Simpangan baku (standar deviasi) sebesar 0,46934. Nilai devisiasi yang lebih kecil dari nilai ratarata artinya terdapat fluktasi yang rendah pada media exposure di perusahaan yang menjadi sampel.

Variabel pengungkapan CSR memiliki nilai terendah (minimum) sebesar 0,33 persen yaitu peursahaan ASII, APLI, TRST, SKLT dan TCPS sedangkan nilai tertinggi (maksimum) sebesar 1 persen yaitu perusahaan AMFG, INDF, KAEF dan TCID, dengan rata-Nilai rata-rata pada pengungkapan CSR sebesar 0,6439 persen. Nilai rata-rata pengungkapan CSR lebih mendekati nilai maksimum, hal ini berarti rata-rata pengungkapan CSR pada perusahaan manufaktur pada tahun 2014-2016 cenderung tinggi.Simpangan baku (standar deviasi) sebesar 0,2299 persen. Nilai devisiasi yang lebih kecil dari nilai rata-rata artinya terdapat fluktasi yang rendah pada pengungkapan CSR di perusahaan yang menjadi sampel.

Selanjutnya dilakukan uji asumsi klasik, model persamaan regresi berdistribusi normal karena memiliki nilai Kolmogorov Smirnov sebesar bahwa nilai Asymp. Sig (2-tailed) 0,076 lebih besar 0,05.Nilai Durbin Watson sebesar 1,854, oleh karena nilai $1,7319<1,854<2,2681$, maka dapat disimpulkan tidak terdapat autokorelasi antar residual. Tidak terdapat nilai Tolerance yang kurang 
dari 0,1 (10 persen) ataupun nilai VIF yang lebih tinggi dari 10. Oleh karena itu pada model analisis tersebut tidak ditemukan adanya gejala multikolinearitas. Nilai signifikansi masing-masing variabel memiliki nilai yang lebih besar dari $\alpha=$ 0.05. Oleh karena itu tidak terjadi heteroskedastisitas.

Analisis regresi linier berganda ini digunakan untuk menganalisis pengaruh Profitabilitas,Ukuran Perusahaan, Kepemilikan Manajerial dan Media Exposure pada Pengungkapan CSR dengan hasil yang dapat dilihat pada Tabel 4. berikut.

Tabel 4.

Rangkuman Hasil Analisis Regresi Linear Berganda

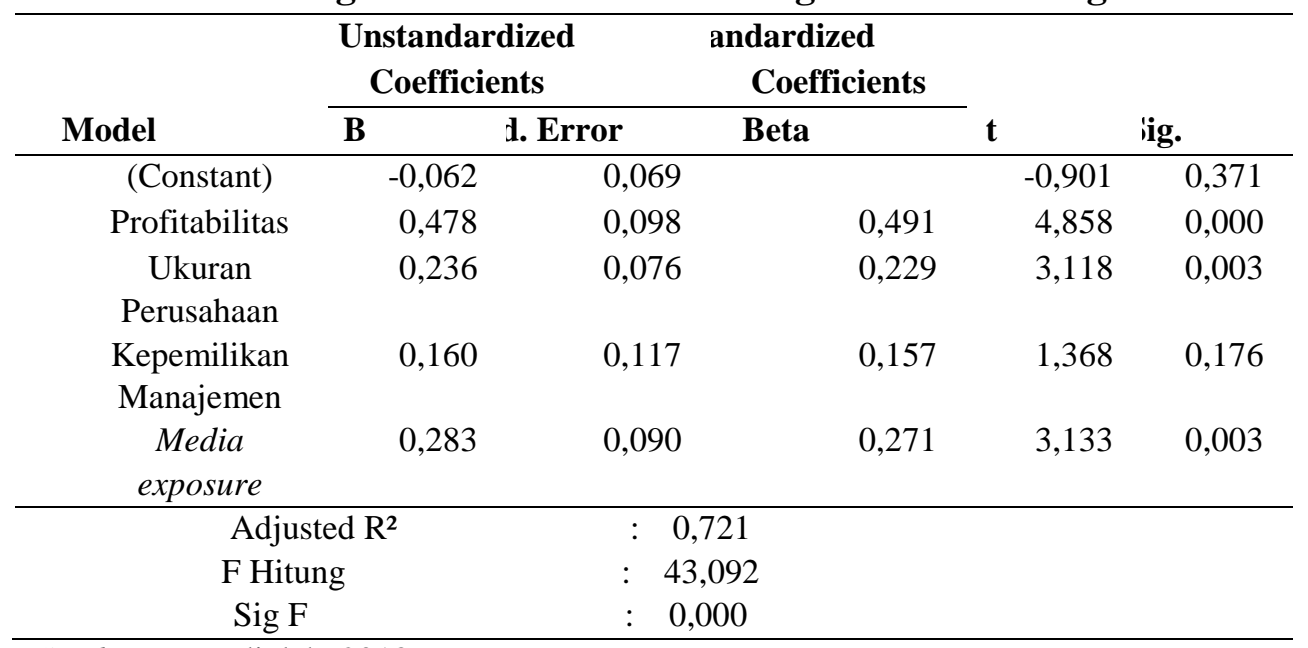

Sumber: Data diolah, 2018

Dari hasil analisis regresi linear berganda pada Tabel 4. tersebut, maka dapat dibuat persamaan sebagai berikut.

$$
Y=-0,062+0,478 X_{1}+0,236 X_{2}+0,160 X_{3}+0,283 X_{4}
$$

Persamaan di atas menunjukan bahwa konstanta sebesar -0,062 memiliki arti apabila profitabilitas, ukuran perusahaan, kepemilikan manajemen, media exposure sama dengan 0 maka nilai pengungkapan corporate social responsibility sebesar -0,062. Profitabilitas 0,478 mempunyai arti bahwa apabila profitabilitas 
naik 1 satuan maka menyebabkan pengungkapan corporate social responsibility naik sebesar 0,478 satuan dengan asumsi variabel lainnya konstan. Ukuran perusahaan 0,236 mempunyai arti bahwa apabila ukuran perusahaan naik 1 satuan maka menyebabkan pengungkapan corporate social responsibility naik sebesar 0,236 satuan dengan asumsi variabel lainnya konstan.

Kepemilikan manajemen 0,160 mempunyai arti bahwa apabila kepemilikan naik 1 satuan maka menyebabkan pengungkapan corporate social responsibility naik sebesar 0,160 satuan dengan asumsi variabel lainnya konstan. Media exposure 0,283 mempunyai arti bahwa apabila media exposure naik 1 satuan maka menyebabkan pengungkapan corporate social responsibility naik sebesar 0,283 satuan dengan asumsi variabel lainnya konstan.

Hasil uji F (Ftest) pada Tabel 4. menunjukkan bahwa nilai signifikansi $\mathrm{P}$ value 0,000 yang lebih kecil dari $\alpha=0,05$, ini berarti model yang digunakan pada penelitian ini adalah layak. Hasil uji memberikan hasil dimana diperoleh besarnya adjusted $\mathrm{R}^{2}$ pada Tabel 4 adalah 0,721 . Ini berarti variasi Pengungkapan CSR dipengaruhi secara signifikan oleh variabel pengaruh profitabilitas,ukuran perusahaan, kepemilikan manajemen dan media exposure sebesar 72,1 persen sedangkan sisanya sebesar 27,9 persen dijelaskan oleh faktor-faktor lain.

Pengujian Hipotesis pertama menunjukan hasil bahwa profitabilitas berpengaruh positif signifikan pada pengungkapan corporate social responsibility.Maka hipotesis yang menyatakan bahwa profitabilitas berpengaruh positif pada Pengungkapan corporate social responsibility diterima.Tingkat profitabilitas berpengaruh positif pada pengungkapan corporate social 
Ketut Yoga Permadiswara dan Ketut Sujana. Pengaruh...

responsibility maka semakin tinggi tingkat profitabilitas maka pengungkapan CSR akan semakin luas. Perusahaan di Indonesia akan meningkatkan pengungkapan tanggung jawab sosial ketika memperoleh profit yang tinggi. Artinya bahwa perusahaan di Indonesia sudah mulai menganggap penting keberadaan pengungkapan tanggung jawab sosial. Sehingga semakin besar keuntungan yang diperoleh akan semakin tinggi juga nilai dari kinerja CSR yang dilakukan. Hal ini dikaitkan dengan teori agensi dengan premis bahwa perolehan laba yang semakin besar akan membuat perusahaan mengungkapkan informasi sosial yang lebih luas.Hasil penelitian ini mendukung penelitian yang dilakukan oleh Sembiring (2005), Roberts (1992), Linda dan Erlin (2012) dan Rindawati (2016)

Pengujian hipotesis kedua menunjukan hasil bahwa ukuran perusahaan berpengaruh positif signifikan pada pengungkapan corporate social responsibility. Maka hipotesis yang menyatakan bahwa ukuran perusahaan berpengaruh positif pada Pengungkapan corporate social responsibility diterima.

Ukuran perusahaan berpengaruh terhadap pengungkapan informasi tanggung jawab sosial. Perusahaan besar akan cenderung mengungkapkan informasi lebih banyak karena ia memiliki sumber daya yang besar sehingga mampu membiayai penyediaan informasi sosial dan lingkungan yang lebih lengkap dibandingkan perusahaan kecil. Selain itu, perusahaan besar merasa bahwa mereka merupakan target perhatian sehingga perlu untuk membuat suatu usaha nyata dalam menciptakan kepercayaan dalam hal pertanggung jawaban sosial. Mengungkapkan informasi mengenai aktivitas perusahaan yang berkaitan 
dengan lingkungan hidup menjadi salah satu upaya perusahaan untuk mewujudkan pertanggungjawaban sosial.

Perusahaan-perusahaan besar merupakan emiten yang banyak disoroti, pengungkapan yang lebih besar merupakan pengurangan biaya politis sebagai wujud tanggung jawab sosial perusahaan (Sembiring, 2005). Cowen et. al., (1987) dalam Sembiring (2005) secara teoritis perusahaan besar tidak akan lepas dari tekanan, dan perusahaan yang lebih besar dengan aktivitas operasi dan pengaruh yang lebih besar terhadap masyarakat mungkin akan memiliki pemegang saham yang memperhatikan program sosial yang dibuat perusahaan sehingga pengungkapan tanggung jawab sosial perusahaan akan semakin luas. Hasil penelitian ini konsisten dengan hasil penelitian yang dilakukan Ridawati (2016), Dewi (2013) dan Sembiring (2005).

Pengujian Hipotesis ketiga menunjukan hasil bahwa kepemilikan manajemen tidak berpengaruh pada pengungkapan corporate social responsibility. Maka hipotesis yang menyatakan bahwa kepemilikan manajemen berpengaruh positif pada Pengungkapan corporate social responsibility ditolak. Kepemilikan manajemen tidak berpengaruh terhadap pengungkapan corporate social responsibility dikarenakan kepemilikan manajemen pada perusahaan keuangan di Indonesia masih rendah dapat dilihat di statistik deskriptif, oleh karena itu kinerja manajemen juga cenderung rendah sehingga tidak mempengaruhi nilai perusahaan (Permana, 2010). Kepemilikan manajemen yang redah mengakibatkan kinerja yang belum maksimal sehingga kepemilikan manajemen belum dapat menjadi mekanisme untuk meningkatkan reputasi 
Ketut Yoga Permadiswara dan Ketut Sujana. Pengaruh...

perusahaan. Che Haat et al. (2008) menemukan bahwa insider ownership tidak berpengaruh terhadap kinerja perusahaan yang diproksi dengan Tobin's Q. Hasil penelitian ini konsisten dengan penelitian yang dilakukan oleh Lemons and Lins (2001), dan Lins (2002).

Pengujian Hipotesis keempat menunjukan hasil bahwa media exposure berpengaruh positif signifikan pada pengungkapan corporate social responsibility.Maka hipotesis yang menyatakan bahwa Media Exposure berpengaruh positif pada Pengungkapan corporate social responsibility diterima.Hal ini berarti bahwa perusahaan yang mengkomunikasikan CSR di website resminya maka perusahaan akan mengungkapkan CSR yang lebih luas untuk meningkatkan citra perusahaan.

Perusahaan yang mengungkapkan kegiatan sosialnya pada website perusahaan dinilai transparan terhadap masyarakat luas karena perusahaan memberikan secara umum, jika perusahaan menganggap akan mampu untuk memberikan informasi yang lebih detail pada laporan keuangan yang sifatnya lebih khusus untuk para pihak yang memiliki kepentingan lebih dengan perusahaan. Pengungkapan informasi secara suaka rela, selektif dan dimakduskan untuk meningkatkan hubungan anatara manajemen dan stakeholder (Harte dan Owen, 1991). Hasil penelitian ini konsisten dengan penelitian yang dilakukan Respati dan Hadiprajitno (2015), Kristi (2012) dan Reverte (2009) dan Sujoko dan Subiantoro (2007).

Berdasarkan hasil pembahasan yang telah dilakukan menunjukan bahwa prfitabilitas, ukuran perusahaan dan media exposure berpengaruh positif pada 
pengungkapan corporate social responsibility. Hal ini mendukung teori agensi yang menyatakan semakin besar profitabilitas dan ukuran perusaan akan membuat perusahaan mengungkapkan informasi sosial yang lebih luas dan teori legitimasi yang menyatakan jika perusahaan ingin mendapatkan kepercayaan dan legitimasi melalui kegiatan corporate social responsibility maka perusahaan harus mempunyai media untuk mengungkapkan informasi agar kebutuhan akan informasi para pemangku kepentingan dan mengkomunikasikan nilai-nilai perusahaan kepada masyarakat terpenuhi.

Kepemilikan manajemen pada penelitian ini menunjukan pengaruh pada pengungkapan corporate social responsibility. Hal ini tidak sesuai dengan teori agensi yang menyatakan semakin kecil pemilikan manajer maka konflik yang terjadi antara agent dan principal semakin besar karena manajer akan mementingkan kepentingan pribadi dibandingkan kepentingan perusahaan.

Hasil penelitian ini menunjukan kepemilikan manajemen secara empiris tidak dapat dijadikan refrensi untuk manajemen perusahaan mengambil keputusan untuk mengungkapkan corporate social responsibility, sebaliknyaprofitabilitas, ukuran perusahaan, dan media exposure dapat menjadi pertimbangan dan referensi dalam pengambilan keputusan untuk mengungkapkan tanggung jawab sosial.Praktik pengungkapan CSR sangat penting untuk meningkatkan reputasi perusahaan sehingga investor tertarik untuk berinvestasi selain itu corporate social responsibility merupakan investasi perusahaan demi pertumbuhan dan berkelanjutan (sustainability and growth). 
Ketut Yoga Permadiswara dan Ketut Sujana. Pengaruh...

\section{SIMPULAN}

Berdasarkan hasil analisis dan pembahasan yang telah diuraikan, maka simpulan yang diperoleh sebagai berikut: 1). Profitabilitas berpengaruh positif signifikan pada pengungkapan Corporate Social Responsibility (CSR). Perolehan laba yang semakin besar akan membuat perusahaan mengungkapkan informasi sosial yang lebih luas; 2). Ukuran perusahaan berpengaruh positif signifikan pada pengungkapan Corporate Social Responsibility (CSR). Perusahaan yang lebih besar dengan aktivitas operasi dan pengaruh yang lebih besar terhadap masyarakat mungkin akan memiliki pemegang saham yang memperhatikan program sosial yang dibuat perusahaan sehingga pengungkapan tanggung jawab sosial perusahaan akan semakin luas; 3). Kepemilikan manajemen tidak berpengaruh pada pengungkapan Corporate Social Responsibility (CSR). Hasil penelitian ini menunjukan bahwa kepemilikan manajemen yang redah mengakibatkan kinerja yang belum maksimal sehingga kepemilikan manajemen belum dapat menjadi mekanisme untuk meningkatkan reputasi perusahaan; 4). Media exposure berpengaruh positif signifikan pada pengungkapan Corporate Social Responsibility (CSR). Perusahaan yang mengkomunikasikan CSR di website resminya maka perusahaan akan mengungkapkan CSR yang lebih luas untuk meningkatkan citra perusahaan.

Hasil penelitian ini menunjukan kepemilikan manajemen tidak bepengaruh pada pengungkapan corporate social responsibility, penelitian selanjutnya dapat menggunakan sampel yang berbeda.Penelitian selanjutnya bisa merubah variabel independen lainnya yang dapat mempengaruhi pengungkapan corporate social 
responsibility dalam suatu perusahaan, seperti ukuran dewan komisaris, leverage, kepemilikan publik dan tipe industri.

\section{REFERENSI}

Anggraini, F. R. R. 2006. Pengungkapan Informasi Sosial dan Faktor-Faktor yang Mempengaruhi Pengungkapan Informasi Sosial dalam Laporan Keuangan Tahunan. Paper dipresentasikan pada acara Simposium Nasional Akuntansi IX Padang. .

Barkemeyer, R. 2007. Legitimacy as a Key Driver and Determinant of CSR in Developing Countries. Paper for the 2007 Marie Curie Summer School on Earth System Governance, Amsterdam University of St Andrews \& Sustainable Development Research Centre (SDRC) School of Management, 1-23.

Che Haat, M. H., Abdul Rahman, R., Mahenthiran, S. 2008. Corporate governance, transparency and performamce of Malaysian companies. Managerial Auditing Journal, 23 (8), 744-778.

Dermawan, D., \& Deitiana, T. 2014. Faktor-Faktor Yang Mempengaruhi Pengungkapan Corporate Social Responsibility ( CSR ). Jurnal Bisnis Dan Akuntansi, 16 (2), 1-8.

Dewi, Sukmawati Savitri.2013. Pengaruh Karakteristik Perusahaan Terhadap Corporate Social Responsibility Pada Perusahaan Manufaktur Yang Terdaftar di BEI. Jurnal Ilmu \& Riset Akuntansi, 2 (3), 25-45.

Gamerschlag, R., Moller, K., \& Verbeeten, F. 2011. Determinants of Voluntary CSR Disclosure: Empirical Evidence from Germany. Jurnal of Management Science, 5, 233-262

Gray, R., Kouhy, R., Lavers, S. 1995. Constructing A Reseacrh database of social and environmental reporting by UK Companies. Accounting Auditing and Accountability Journal , 8, 47-77.

Hackston, D., Milne, M. J. 1996. Some determinants of social and environmental disclosures in New Zealand companies. Accounting, Auditing \& Accountability Journal, 9 (1), 77-108.

Harte George, and Owen David, 1991. Environmental Disclosure In The Annual Reports Of British Companies: A Research Note. Accounting Auditing \& Accountability Journal, 51-61.

Ingram, R., Frazier, K. 1980. Environmental performance and corporate disclosure. Journal of Accounting Research, 612-622. 
Jensen, M. C., \& Meckling, W. H. 1976. Theory of the firm: Managerial behavior, agency costs and ownership structure. Journal of Financial Economics, 3(4), 305-360.

Kristi, A. A. 2012. Faktor-Faktor Yang Mempengaruhi Pengungkapan CSR Pada Perusahaan Publik. Jurnal Akuntansi Brawijaya, 1-27.

Linda, S., Erlin, C. 2012. Dengan Pengungkapan Corporate Social Responsibility. Jurnal Bisnis Dan Akuntansi, 1 (2), 17-30.

Lemons, Michael and karl, lins 2001. Ownership Structur Corporate Governance, and Firm Value. Evidence from the East Asian Financial Crisis, William Davidson Working Paper, 393-416.

Lins, K. V. 2002. Equity Ownership and Firm Value in Emerging Markets. Forthcoming in The Journal of Financial and Quantitative Analysis, 1-38.

Respati, R. D., \& Hadiprajitno, P. B. 2015. Perusahaan, Tipe Industri, Dan Pengungkapan Media Terhadap Pengungkapan Corporate Social Responsibility, 4 (4), 1-11.

Reverte, C. 2009. Determinants of corporate social responsibility disclosure ratings by Spanish listed firms. Journal of Business Ethics, 88 (2), 351366.

Roberts, R. W. 1992. Determinants Of Corporate Social Responsibility Disclosure: An Application Of Stakeholder Theory. Accounting, Organisations and Society, 17 (6), 95-612.

Rockness, J.W. 1985. An Assessment of the Relationship Between US Corporate Environmental Performance and Disclosure. Journal of Business Finance, 12 (3), 339-343.

Sakania, P., Merta, M. 2011. Tanggung Jawab Sosial Pada Laporan Keuangan Perusahaan Lq45 Di Bursa Efek Indonesia. E-Jurnal Akuntansi, 1-11

Sembiring, E. R. 2005. Karakteristik Perusahaan Dan Pengungkapan Tanggung Jawab Sosial: Study Empiris Pada Perusahaan Yang Tercatat Di Bursa Efek Jakarta. Simposium Nasional Akuntansi VIII, 6(9), 379-395.

Sugiyono. 2017. Metode Penelitian Pendidikan Pendekatan Kuantitatif, Kualitatif, dan $R \& D$. Bandung: Alfabeta

Sujoko, Ugy Subiantoro. 2007. Pengaruh Struktur Kepemilikan Saham, Leverage, Faktor Intern Dan Faktor Ekstern Terhadap Nilai Perusahaan. Jurnal Manajemen dan Kewirausahaan, 9 (1), 41-48. 
Wiseman, J. 1982. An Evaluation of Environmental Disclosures Made in Corporate Annual Reports. Accounting, Organizations and Society, 7, 5363.

Yuliskayani, Damayanthi, E. 2018. Consumer Proximity, Media Exposure , Enviromental Sensitivity dan Profitability dalam Memengaruhi CSRD di Indonesia. E-Jurnal Akuntansi, 23 (3), 1651-1681. 